\title{
A taxonomic reconsideration of some Plasmodium species from Iguanid lizards
}

\author{
by S. R. TELFORD Jr. * \\ The Florida State Museum, University of Florida, Gainesville, Florida, U.S.A.
}

\section{Résumé.}

\author{
Reconsidération taxonomique de quelques espèces de Plasmodium de lézards \\ Iguanidés.
}

Les populations de Plasmodium des Sauriens classées antérieurement comme $P$. tropiduri de Panama sont décrites comme des sous-espèces ou des espèces distinctes. La sous-espèce appelée $P$. tropiduri tropiduri parasite les espèces Tropidurus du Brésil, de la Guyane et du Venezuela. Deux autres sous-espèces existent au Panama, $P$. tropiduri panamense, parasite d'Anolis biporcatus et $P$. tropiduri aquaticum, parasite des lézards semi-aquatiques Anolis lionotus et $A$. poecilopus. Les parasites trouvés chez Anolis frenatus sont décrits comme une espèce distincte, $P$. marginatum, tandis que ceux d'Anolis limifrons représentent une troisième espèce non nommée. Un parasite de Plica plica en Guyane, auparavant appelé $P$. cnemidophori est dénommé $P$. guyannense tandis que les parasites de Plica umbra qui étaient classés $P$. tropiduri deviennent $P$. vacuolatum et Fallisia simplex.

\section{Summary.}

Saurian Plasmodium populations previously identified as P. tropiduri from Panama are described as subspecies or distinct species. The nominate subspecies, $P$. tropiduri tropiduri parasitizes Tropidurus species from Brazil, Guyana and Venezuela. Two other subspecies occur in Panama, P. tropiduri panamense from Anolis biporcatus and P. tropiduri aquaticum from the semi-aquatic lizards Anolis lionotus and A. poecilopus. Parasites found in Anolis frenatus are described as a distinct species, P. marginatum, while those from Anolis limifrons represent a third, un-named species. A parasite of Plica plica in Guyana, previously called $P$. cnemidophori, is designated P. guyannense, while identification of Plica umbra parasites as $P$. tropiduri is corrected to $P$. vacuolatum and Fallisia simplex.

* Current address : Rodent Control Demonstration Unit, c/o The WHO Programme Coordinator, P.O. Box No. 14, Rangoon, Burma.

Accepté le 11 août 1978 . 
In three studies on Neotropical saurian malarias (Telford, 1973, 1974, 1977), I have made certain identifications of species which have been criticized by others (Lainson, Shaw and Landau, 1975; Ayala and Spain, 1976; Guerrero, Rodriguez and Ayala, 1977 ; Guerrero and Ayala, 1977). Recently I have examined additional material, including some not previously available, and have concluded that my colleagues are probably right: in seeking a conservative approach, I have too readily «lumped » certain distinct species together. I present here a taxonomic arrangement of some saurian plasmodiid parasites which I think provides a better classification of them until their relationships can be studied by more precise methods than light microscopy.

Most of the confusion commented upon by Dr. Ayala (1977) is due to the failure of most workers to state clearly the stage of infection used to prepare taxonomic descriptions. Identifications and descriptions are best based upon active infections for these usually reveal the full extent of variation to be expected for most species. As infections reach peak, crisis forms may appear and predominate until chronicity is established. Crisis stage schizonts are smaller and produce fewer nuclei, which reduces both range and mean of dimensions. Gametocytes are less obviously affected at crisis but may be smaller. Aberrant forms may or may not appear at crisis. Chronic phase schizonts fall within the range of variation found in active phase but usually show slightly smaller mean values, while gametocytes frequently have dimensions exceeding those seen in active infections. These variations due to infection stage must be considered in making taxonomic decisions among Plasmodium species which are as similar as those within the $P$. tropiduri group. Without experimental infections, however, or application of modern biochemical and immunological techniques, conspecificity is only based upon best taxonomic judgment. In description below, I have compared, where material permitted, infections which were active (including acute), at crisis, and chronic.

\section{Materials and methods}

The procedures used in studying saurian malarial infections and characters useful in distinguishing species have been presented in detail in earlier papers (Telford, 1973, 1974 and others). Certain additional characters need definition. A quantification of schizont size as LW (maximum length $\times$ maximum width) is useful both in interspecific comparisons and in describing morphological differences correlated with infection stage. The $\mathrm{L} / \mathrm{W}$ ratio of gametocytes provides a quantitative estimate of shape. As used here, round gametocytes have $\mathrm{L} / \mathrm{W}$ ratios between 1.0-1.4, oval are 1.4-1.8, and those exceeding 1.8 are elongate. Effect of parasite upon host cell is useful both in inter and intra - specific comparisons, especially in determining effects of the same parasite species upon different hosts. Subjective comparisons of infected cells with normal cells of the same type around them permit estimates of the percentage of infected cells which show distortion of cell and nucleus, and displacement of the latter. One must allow for distortion produced by making the smear. A quantitative estimate of effect 
upon host cell is provided by comparison of mean host cell LW and nucleus LW against those of normal erythrocytes, of which I measure 10 on each slide examined.

Infection stage was estimated from determining level of parasitemia and anemia, relative proportions of asexual and sexual stages, and in some cases, from prolonged observation of the infection during which a change of phase occured. Samples of 35-125 parasites were used to determine relative proportions of trophozoites, schizonts, segmenters, immature and mature gametocytes, and level of parasitemia was based upon counts of 300-1500 red blood cells, depending upon infection level. Absence or presence of pigment was verified by polarized light. Illustrations are available in previous papers (Telford, 1973, 1974).

Data below are presented as observed range, range of means from individual infections, or means from single infections, in which case one standard error of the mean is stated. All measurements, taken with calibrated ocular micrometer, are expressed in micrometers or the square thereof for LW statistics. Both Student-t and chi square tests were used when necessary to verify significant differences, at level of $\mathrm{p} \leqslant .05$.

\section{Results}

This study is based upon examination of 361 infections from lizards of the genera Tropidurus and Anolis from Panama, Costa Rica, Venezuela and Guyana. Detailed observations, primarily measurements, were made from 1271 parasites of 32 natural infections, selected on criteria of infection stage, level of parasitemia, quality of preparation and area of origin. Table 1 presents characteristics of strains used for preparing the descriptions below of the $P$. tropiduri group parasites. A decision to recognize subspecies among saurian malarias was based upon precedent by Garnham (1966) who has employed effectively the trinomial to distinguish morphologically/ physiologically different parasite populations which are found in separate geographic areas or host species.

\section{Plasmodium populations previously reported as $\boldsymbol{P}$. tropiduri.}

Apart from my own composite description (Telford, 1974), there has been no recent published definition of Plasmodium tropiduri, based upon material from iguanid hosts. I present below a definition of this species and descriptions of three populations as subspecies.

\section{Plasmodium tropiduri}

Aragão and Neiva, 1909

Definition : A saurian malaria parasite characterized by mature schizonts formed usually as a rosette or fan, which contain 4-24 nuclei and are usually slightly smaller than normal erythrocyte nuclei. The mean number of nuclei in individual infections ranges 5.3-17.3, and with schizont size and shape varies according to host species, stage of infection and type of red blood cell parasitized. Gametocytes are round to 
oval, seldom elongate except when lateral to host cell nucleus, with mean length/width ratios $(\mathrm{L} / \mathrm{W})$ in individual infections $1.1-1.6$. Size $(\mathrm{LW})$ ranges $16-80 \mu \mathrm{m}^{2}$, with means of individual infections 26-60 $\mu \mathrm{m}^{2}$. Both size and shape vary with host species, stage of infection and type of red blood cell. Gametocyte size relative to that of uninfected erythrocyte nuclei is $0.6-1.5$, with ratio varying with host species. Pigment is always present in schizonts and gametocytes unless the parasite occupies an immature erythrocyte, in which case its presence and quantity may be variable. Pigment masses in schizonts and immature gametocytes are golden yellow; these become dispersed as minute dark granules in the cytoplasm of mature gametocytes. Trophozoites and schizonts usually parasitize proerythrocytes while gametocytes are more common in erythrocytes. Younger asexual stages are not highly amoeboid, and lack prominent cytoplasmic processes. Schizonts and gametocytes usually occupy polar or lateropolar positions in host cells. Host cells are distorted more commonly than their nuclei, which are frequently displaced. Both schizonts and gametocytes can produce significant hypertrophy of host cell and its nucleus, but this varies with host species and stage of infection.

Host AND GEOGRAPHIC RANGE: Iguanid lizards of the genera Tropidurus and Anolis from southeastern Brazil to Costa Rica.

\section{Descriptions of subspecies}

\section{Plasmodium tropiduri tropiduri}

Aragão and Neiva, 1909

Diagnosis: A population of Plasmodium tropiduri which parasitizes Tropidurus species in Brazil, the Guianas and Venezuela. Schizonts in active infections are larger than uninfected erythrocyte nuclei, and contain 8-22 nuclei usually arranged as a rosette. Schizont size may average smaller and nuclei fewer in mature host cells in comparison to immature, or during other stages of infection. Gametocytes are usually round or oval and are larger than nuclei of uninfected erythrocytes. Pigment presence is constant in schizonts and erythrocytes.

DESCRIPTION : In active infections in Tropidurus hispidus schizonts were 5-10 $\times$ 3-7 $\mu \mathrm{m}(\overline{\mathrm{x}} 5.9-8.4 \times 4.5-5.3)$, with LW values averaging 26.7-44.0 $\mu \mathrm{m}^{2}$ (20-63), and contained 8-22 nuclei ( $\overline{\mathrm{x}} 10.8-17.3$ ). In proerythrocytes schizonts were larger and contained more nuclei (14-22) than in erythrocytes (8-14). Most formed as a rosette $(74 \%)$, less commonly as a fan $(15 \%)$ or otherwise, and all were pigmented. They occupied polar $(74 \%)$ or lateropolar positions in cells, seldom lying lateral $(6 \%)$ to the nucleus. Host cells were sometimes distorted (24\%) and nuclei were commonly displaced $(54 \%)$ but not distorted. Gametocytes were $6-10 \times 4-7 \mu \mathrm{m}(\overline{\mathrm{x}} 7.8 \times 5.4-5.6)$ with LW averaging 41.8-42.7 $\mu \mathrm{m}^{2}$ (30-56). They were usually round (57\%) or oval, 
seldom elongate $(11 \%)$, with $\mathrm{L} / \mathrm{W}$ ratios averaging $1.42-1.47$ (1.0-2.3). Size relative to host cell nucleus averaged 1.30-1.54 (0.9-2.3). All were pigmented and many showed a single vacuole $(69 \%)$. Gametocytes usually occupied polar positions in host cells $(68 \%)$ or lateropolar, rarely being lateral to host cell nucleus $(3 \%)$. Host cells were seldom distorted $(8 \%)$ but their nuclei were often displaced $(60 \%)$ though not distorted. Both schizonts and gametocytes caused significant hypertrophy to host cells and their nuclei.

In infections at crisis in both $T$. hispidus and $T$. torquatus, schizonts were smaller, $3-5 \times 2-4 \mu \mathrm{m}$ (respective $\overline{\mathrm{x}} 4.1 \times 3.6$ and $4.4 \times 3.3-3.7$ ), with $\mathrm{LW}$ values averaging 14.5-16.5 $\mu \mathrm{m}^{2}$ (9-20) and fewer nuclei, $4-10(\overline{\mathrm{x}} 6.0$ and 6.4-7.8, respectively). Schizonts were formed more commonly as fans $(53 \%)$ than as rosettes $(38 \%)$ or otherwise, and occupied polar $(91 \%)$ or lateropolar positions in cells. Schizonts in T. hispidus seldom distorted host cells $(10 \%)$ and neither displaced nor distorted their nuclei, producing no hypertrophy. In $T$. torquatus host cells were not distorted while nuclei were rarely (3\%) displaced or distorted. Both host cell and nucleus, however, showed significant hypertrophy. Gametocytes of both host species were similar in dimensions and smaller than in active infections, 5-9 $\times$ 4-6 $\mu \mathrm{m}(\overline{\mathrm{x}} 5.6-6.7 \times 4.7-5.4)$, with LW averaging 26.4-34.6 $\mu \mathrm{m}^{2}$ (20-54). Fewer were elongate (3\%), most being round (54\%) or oval, with $\mathrm{L} / \mathrm{W}$ ratios averaging $1.18-1.41(1.0-2.0)$. Size relative to host cell nucleus was smaller on average, 0.96-1.15 (0.6-2.1). A vacuole was more often present $(89 \%)$. Gametocytes usually occupied polar $(74 \%)$ or lateropolar positions in host cells, seldom being lateral $(6 \%)$. They seldom distorted host cells $(8-11 \%)$ or their nuclei ( $2 \%)$, and less often displaced the latter $(47 \%)$. Gametocytes from T. torquatus produced significant hypertrophy of host cells but not their nuclei, in contrast to those of $T$. hispidus where no hypertrophy occurred.

In chronic infections schizont dimensions fell within limits of active infections, with average LW values $47.7 \pm 1.9$ (35-60) in $T$. hispidus and $23.4 \pm 2.9 \mu \mathrm{m}^{2}(15-35)$ in $T$. torquatus, containing $13-24(17.0 \pm 0.8)$ and 4-12 $(8.5 \pm 1.1)$ nuclei, respectively. The infection from $T$. hispidus appeared to be recrudescent in contrast to a newly chronic infection in $T$. torquatus. Schizont shape was usually a rosette in both hosts $(63-80 \%)$ with nuclei commonly arranged also as a fan in $T$. torquatus $(37 \%)$ or more variably in $T$. hispidus (20\%). Schizonts of both strains were most commonly in polar position $(80-88 \%)$ or lateropolar, with some lateral to the nucleus in $T$. hispidus $(13 \%)$. Effects upon host cells were more evident with $T$. hispidus as a consequence, perhaps, of larger schizonts : both host cell (47\%) and nucleus $(27 \%)$ were commonly distorted, and the nucleus displaced $(60 \%)$, in contrast to host cells of $T$. torquatus which appeared normal. Hypertrophy of host cell but not nuclei was evident in each strain. Gametocytes in $T$. torquatus were $5-7 \times 5-7 \mu \mathrm{m}(\overline{\mathrm{x}} 6.3 \pm .2 \times 5.4 \pm .2)$, with LW averaging $34.0 \pm 1.7 \mu \mathrm{m}^{2}(25-49)$. They were round $(80 \%)$ or oval, with $\mathrm{L} / \mathrm{W}$ ratios $1.0-1.4(\overline{\mathrm{x}} 1.17 \pm .04)$ and slightly larger than host cell nuclei, on average $1.08 \pm .04(0.9-1.4)$. They seldom distorted host cells $(13 \%)$ or nuclei $(7 \%)$ but commonly displaced the latter $(40 \%)$. No hypertrophy was evident. Gametocytes from chronic $T$. hispidus infections had dimensions only slightly larger than those of 
Table I. - Characteristics of Plasınodium tropiduri s.l. infections studied.

\begin{tabular}{|c|c|c|c|c|c|c|c|}
\hline \multirow{3}{*}{$\begin{array}{c}\text { Host species } \\
\text { Tropidurus hispidus }\end{array}$} & \multirow{3}{*}{$\begin{array}{l}\text { Infection stage } \\
\text { active }\end{array}$} & \multirow{3}{*}{$\begin{array}{c}\begin{array}{c}\text { Parasi- } \\
\text { temia } \\
\%\end{array} \\
2.3\end{array}$} & \multirow{3}{*}{$\begin{array}{c}\begin{array}{c}\text { Ane- } \\
\text { mia } \\
\%\end{array} \\
22.3\end{array}$} & \multirow{3}{*}{$\begin{array}{c}\begin{array}{c}\text { Asexual: } \\
\text { Sexual } \\
\text { ratio }\end{array} \\
72: 28\end{array}$} & \multirow{2}{*}{\multicolumn{2}{|c|}{$\begin{array}{l}\text { No. parasites } \\
\text { measured } \\
\text { schi- game- } \\
\text { zonts tocytes }\end{array}$}} & \multirow{3}{*}{$\begin{array}{c}\text { Origin } \\
\begin{array}{c}\text { Central } \\
\text { Venezuela }\end{array}\end{array}$} \\
\hline & & & & & & & \\
\hline & & & & & 25 & 25 & \\
\hline ” & acute & 22.6 & 32.5 & $96: 04$ & 25 & 25 & $"$ \\
\hline " & crisis & 0.4 & 8.4 & $73: 27$ & 10 & 25 & $"$ \\
\hline ” & chronic (new) & 0.2 & 0.8 & $76: 24$ & 0 & 25 & $"$ \\
\hline ” & chronic (old) & 0.04 & 6.1 & $07: 93$ & 0 & 25 & $"$ \\
\hline ” & recrudescent & 0.1 & 8.0 & $83: 17$ & 15 & 7 & $"$ \\
\hline Tropidurus torquatus & crisis & 0.4 & 1.5 & $89: 11$ & 25 & 25 & Guyana \\
\hline 》 & crisis & 0.4 & 19.1 & $72: 28$ & 10 & 10 & $"$ \\
\hline ” & chronic (new & 0.3 & 32.6 & $75: 25$ & 8 & 11 & $"$ \\
\hline " & chronic (old) & 0.2 & 15.0 & $20: 80$ & 0 & 4 & 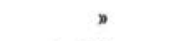 \\
\hline Anolis biporcatus & active & 0.3 & 23.4 & $74: 26$ & 6 & 10 & central Panama \\
\hline " & active & 0.3 & 30.6 & $82: 18$ & 25 & 25 & " \\
\hline & active & 1.2 & 21.3 & $79: 21$ & 25 & 25 & ” \\
\hline$"$ & active & 2.4 & 38.2 & $82: 18$ & 10 & 0 & " \\
\hline$"$ & acute & 3.3 & 34.2 & $74: 26$ & 51 & 50 & " \\
\hline$"$ & crisis & 0.5 & 23.7 & $82: 18$ & 7 & 15 & $"$ \\
\hline$"$ & crisis & 0.2 & 79.7 & $69: 31$ & 12 & 10 & $"$ \\
\hline$"$ & chronic & 1.7 & 26.1 & $73: 27$ & 26 & 19 & " \\
\hline Anolis lionotus & active & 5.3 & 50.5 & $81: 19$ & 25 & 20 & central Panama \\
\hline ग & active & 6.0 & 51.7 & $63: 37$ & 25 & 23 & $"$ \\
\hline " & active & 6.1 & 49.9 & $60: 40$ & 25 & 20 & $"$ \\
\hline$”$ & chronic & 0.8 & 60.5 & $63: 37$ & 16 & 25 & $"$ \\
\hline 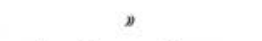 & recrudescent & 0.6 & 42.8 & $89: 11$ & 25 & 15 & $"$ \\
\hline Anolis poecilopus & active & 2.4 & 63.7 & $72: 28$ & 25 & 17 & $"$ \\
\hline 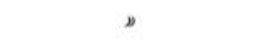 & active & 2.7 & 69.4 & $71: 29$ & 25 & 25 & $"$ \\
\hline " & crisis & 0.8 & 82.7 & $74: 26$ & 25 & 19 & $"$ \\
\hline & crisis & 1.2 & 89.0 & $79: 21$ & 9 & 10 & $"$ \\
\hline$»$ & chronic & 0.1 & 54.0 & $60: 40$ & 0 & 12 & $"$ \\
\hline Anolis frenatus & active & 0.6 & 69.0 & $96: 04$ & 25 & 24 & $”$ \\
\hline 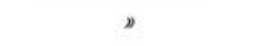 & active & 1.6 & & $93: 07$ & 25 & 0 & $"$ \\
\hline ” & acute & 16.9 & & $99: 01$ & 25 & 50 & $"$ \\
\hline$"$ & crisis & 0.7 & 9.5 & $97: 03$ & 25 & 0 & $"$ \\
\hline Anolis limifrons & active & 1.2 & 12.5 & $76: 24$ & 20 & 0 & $"$ \\
\hline " & acute & 18.0 & 47.2 & $75: 25$ & 25 & 50 & $"$ \\
\hline
\end{tabular}


active infections, $6-14 \times 4-8 \mu \mathrm{m}(\mathrm{x} 7.9-9.5 \times 6.0-6.3)$ but showed significantly greater LW values which averaged 47.5-59.8 $\mu \mathrm{m}^{2}$ (30-80). An elongate shape was more common $(18 \%)$ although most remained round $(54 \%)$ or oval, with $\mathrm{L} / \mathrm{W}$ ratios averaging 1.34-1.53 (1.0-3.5). Size relative to host cell nucleus was greater, averaging 1.56-1.96 (0.9-2.9). Vacuoles were less commonly present $(40 \%)$. Host cell $(72 \%)$ and nuclear distortion (19\%) were more evident in older chronic infections where gametocytes were larger than in younger (32\% and $4 \%$, respectively), but nuclear displacement was similar in all $(92 \%)$. Hypertrophy of host cell nucleus was seen only in younger chronic infections, with host cells and nuclei normal in size in older infections.

Type Locality: Bicudos, Minas (Gerais), Brazil.

\section{Plasmodium tropiduri panamense}

Subsp. nov.

DiAgNosis: A population of Plasmodium tropiduri which parasitizes Anolis biporcatus in Panama. Schizonts are smaller than nuclei of uninfected erythrocytes and contain 4-18 nuclei usually arranged as a rosette. Both size of schizont and number of nuclei average larger in proerythrocytes than in erythrocytes. Gametocytes are usually oval or round and are slightly smaller than nuclei of uninfected erythrocytes. Schizonts parasitize proerythrocytes predominantly and are seldom pigmented. Gametocytes are more common in erythrocytes with presence of pigment variable, correlated with host cell maturity, but apparently more commonly present as infections progress to chronic stage.

DESCRIPTION: In active stage of infection schizonts were 4-8 $\times 3-6 \mu \mathrm{m}$ ( $\mathrm{x}$ 5.1-6.8 $\times$ 3.7-4.4), averaging 19.3-29.5 $\mu \mathrm{m}^{2}(12-40)$ in LW, and contained 4-8 nuclei ( $\mathrm{x} 7.8-12.0)$. Dimensions of schizonts in proerythrocytes were larger, with greater resultant LW values $\left(\overline{\mathrm{x}} 22.2 \pm .6 \mu \mathrm{m}^{2}, \mathrm{~N}=128\right)$ than when erythrocytes were host cells $(\overline{\mathrm{x}} 15.9 \pm 1.3, \mathrm{~N}=14)$. More nuclei ( $\mathrm{x} 9.3 \pm .3$ ) were produced than in mature cells ( $\overline{\mathrm{x}} 6.6 \pm .7$ ). Most schizonts $(97 \%$ ) occupied proerythrocytes, and most lacked visible pigment $(96.5 \%)$. Nuclei were arranged as a rosette $(61 \%)$ or in variable pattern, seldom forming fans $(7 \%)$. Schizonts occupied polar positions $(74 \%)$ or were lateropolar, uncommonly lying lateral $(8 \%)$ to the nucleus. Host cells were commonly distorted $(35 \%)$, and their nuclei displaced $(60 \%)$, but rarely distorted $(3 \%)$. Neither host cell nor nucleus showed hypertrophy. Gametocytes were 5-9 × 3-7 $\mu \mathrm{m}(\overline{\mathrm{x}} 6.4-7.1)$, with LW values averaging 31.1-34.9 $\mu \mathrm{m}^{2}$ (18-56). Dimensions of gametocytes in erythrocytes were slightly larger than in proerythrocytes, with resultant LW values averaging greater $(\overline{\mathrm{x}} 33.9 \pm .8, \mathrm{~N}=94)$ than in immature cells $(\overline{\mathrm{x}} 27.2 \pm 1.0, \mathrm{~N}=31)$. 
Gametocytes were more commonly oval (48\%) or round than elongate $(10 \%)$, with $\mathrm{L} / \mathrm{W}$ ratios averaging $1.27-1.54(1.0-2.7)$. Those in proerythrocytes were slightly more elongate $(1.52 \pm .06)$ than those in mature cells $(1.37 \pm .02)$. Size relative to host cell nucleus averaged $0.79-0.96(0.5-1.6)$. Gametocytes usually parasitized erythrocytes $(69 \%)$, in which pigment was more often visible $(14.5 \%)$ than when proerythrocytes were parasitized $(2.9 \%$ pigmented). Gametocytes were usually polar $(45 \%)$ or lateropolar to the nucleus, although lateral position was common $(24 \%)$. A vacuole was usually seen in gametocytes $(66 \%)$. Host cells were usually distorted $(75 \%)$ with nuclei displaced $(74 \%)$ and sometimes distorted $(20 \%)$. Both host cells and nuclei showed significant hypertrophy.

In infections at crisis schizonts were smaller, 4-5 × 3-4 $\mu \mathrm{m}$, with LW values averaging 13.7-14.6 $\mu \mathrm{m}^{2}(12-20)$, and fewer nuclei, 6.0-6.4 (5-8), arranged as a rosette (63\%) or as a fan $(37 \%)$. Most $(95 \%)$ occupied proerythrocytes in polar position $(95 \%)$. Neither host cells nor their nuclei were distorted and nuclear displacement was less common $(32 \%)$. Both host cell and nucleus were slightly smaller than uninfected cells. Gametocyte dimensions fell within limits of those in active infections but LW values averaged somewhat smaller, 26.7-27.4 $\mu \mathrm{m}^{2}$ (20-36), and shape was more commonly round $(60 \%)$ than oval or elongate $(4 \%)$. Size relative to host cell nucleus was unchanged and position was more often polar (56\%) than lateropolar or lateral $(16 \%)$. The frequency with which parasites occupied erythrocytes approximated active infections $(72 \%)$, but the proportion of gametocytes showing pigment increased $(20 \%)$. Fewer showed vacuoles $(44 \%)$. Host cells were less commonly distorted $(40 \%)$ as were nuclei $(4 \%)$, but nuclear displacement increased $(72 \%)$. Host cells and nuclei were slightly smaller than uninfected cells.

In the single chronic infection studied, schizont dimensions fell within limits for active infections, with mean LW value $18.2 \mu \mathrm{m}^{2}$ (8-32), and nuclei ranging 4-12, $\overline{\mathrm{X}} 7.5 \pm .5(\mathrm{~N}=26)$, arranged usually as a rosette. More occupied erythrocytes $(42 \%)$ and frequency of pigment was greater $(15 \%)$. Fewer were seen in the polar position $(62 \%)$, with more lateropolar $(34 \%)$. Both host cell $(58 \%)$ and nuclei $(19 \%)$ were more commonly distorted, but fewer nuclei were displaced than in active infections $(54 \%)$. Host cells were slightly smaller than uninfected cells, but nuclei showed prominent hypertrophy. Gametocyte dimensions resembled those of active infections but their shape was more commonly round $(58 \%)$ than oval $(42 \%)$. No change was observed in their size relative to host cell nuclei. More gametocytes occupied erythrocytes $(95 \%)$, and pigment was more often present $(37 \%)$. Fewer were seen in polar position $(16 \%)$ than in lateropolar or lateral $(42 \%)$. Host cells were more commonly distorted $(90 \%)$ and nuclei were often displaced $(79 \%)$, but seldom distorted $(11 \%)$. Host cells approximated uninfected cells in size but their nuclei showed significant hypertrophy.

Type locality: El Aguacate, Panama Province, Panama (08 $50^{\prime}$ N, $79^{\circ} 54^{\prime}$ W). 


\section{Plasmodium tropiduri aquaticum}

Subsp. nov.

Diagnosis : A population of Plasmodium tropiduri which parasitizes Anolis lionotus and Anolis poecilopus in Panama and Costa Rica. Schizonts in active infections are smaller than nuclei of uninfected erythrocytes and contain 4-14 nuclei usually arranged as a rosette. Gametocytes are round or oval and are smaller than uninfected erythrocyte nuclei. Schizonts predominantly parasitize proerythrocytes, gametocytes are more commonly found in erythrocytes, and pigment presence is constant in both stages.

DESCRIPTION : In active stage of infection schizonts were 4-8 $\times 3-6 \mu \mathrm{m}(\overline{\mathrm{x}}$ 4.9-5.6 $\times$ 3.9-4.5), averaging 19.1-25.4 $\mu \mathrm{m}^{2}(12-36)$ in LW, and contained 5-14 ( $\left.\overline{\mathrm{x}} 7.7-9.5\right)$ nuclei. All were pigmented, with nuclei usually arranged as rosettes (77\%), occasionally as fans $(11 \%)$ or otherwise. Most schizonts occupied proerythrocytes $(88 \%)$ in preference to erythrocytes, and usually assumed a polar $(76 \%)$ or lateropolar position rather than lateral $(4 \%)$. Nuclei of host erythrocytes were significantly hypertrophied and sometimes displaced $(13 \%)$, but were seldom distorted in shape $(2 \%)$. Host cells did not show hypertrophy and were rarely distorted (2\%). Gametocytes were 4-10 $\times$ 3-6 $\mu \mathrm{m}(\overline{\mathrm{x}} 5.5-6.8 \times 4.3-4.9)$ with $\mathrm{LW}$ values averaging $26.3-30.3 \mu \mathrm{m}^{2}(16-50)$. They were round $(63 \%)$ or oval in shape, seldom elongate $(8 \%)$, with $\mathrm{L} / \mathrm{W}$ ratios averaging $1.15-1.64(1.0-2.5)$. Size relative to that of host cell nuclei averaged $0.55-0.73(0.4-1.0)$. Gametocytes occupied erythrocytes usually $(62 \%)$ in a polar $(82 \%)$ or lateropolar position, seldom being lateral to the nucleus ( $3 \%)$. All were pigmented, often $(45 \%)$ showing a single vacuole. Host cells were not hypertrophied but were occasionally distorted $(11 \%)$, with nuclei commonly displaced $(27 \%)$. Nuclear distortion was rare (3\%) with but slight hypertrophy evident.

At crisis schizonts were smaller, 3-6 $\times 2-5 \mu \mathrm{m}$, with $\mathrm{LW}$ values averaging 11.8-16.7 $\mu \mathrm{m}^{2}(6-25)$ and 4-8 nuclei $(\overline{\mathrm{x}}$ 5.3-6.0). Rosette and fan-shapes were equally common $(33 \%)$ with a higher proportion of variably shaped schizonts $(33 \%)$. Most $(87 \%)$ occupied proerythrocytes in a polar $(60 \%)$ or lateropolar position. Host cell distortion $(10 \%)$ and nuclear displacement $(23 \%)$ were more common than in active infections, but nuclei showed no distortion. Neither host cell nor nucleus showed hypertrophy. Gametocyte length and width fell within their range in active infections, but LW values averaged slightly greater, 31.2-31.5 $\mu \mathrm{m}^{2}(20-54)$. Their shape was rounder, with $\mathrm{L} / \mathrm{W}$ ratios $1.0-1.5(\overline{\mathrm{x}} 1.17-1.20)$, while size relative to that of host cell nucleus was unchanged. Vacuoles were seen in most $(88 \%)$. More gametocytes occupied erythrocytes $(86 \%)$, with no change in position within host cells. Effects upon host cells were more evident : although not hypertrophied, they were commonly distorted $(31 \%)$ with nuclei displaced $(48 \%)$. More nuclei were distorted $(17 \%)$ and hypertrophied.

In chronic infection schizont dimensions resembled those seen in active infection, while nuclei averaged 8.1-8.5 (4-12). Schizonts in recrudescent infection remained 
within limits of active infection. Their shape again was most commonly a rosette (76$81 \%)$ or fan (6-20\%), with fewer variably shaped schizonts than at crisis. More were seen in polar position $(94 \%)$. No distortion of host cells was seen. Host cell nuclei were rarely distorted $(2 \%)$ and less often displaced $(17 \%)$ than at crisis. Neither cells nor nuclei showed hypertrophy. Gametocyte dimensions fell within limits of active infections, but $\mathrm{L} / \mathrm{W}$ ratios reflected a more rounded shape ( $\overline{\mathrm{x}}$ 1.08-1.23) than in active infections, with variability increased during recrudescence. Average size relative to host cell nucleus remained within limits of active infections, but the range extended to 1.4 times host cell nucleus size. Vacuole frequency decreased in chronic infections $(68 \%)$, reaching a minimum in gametocytes of recrudescent infections $(20 \%)$. Gametocytes continued to occupy polar positions most often $(73 \%)$ but in recrudescent infections position became slightly more variable, with lateropolar position more common (33\%). Host cells were not distorted while displacement of nucleus $(23 \%)$ and its distortion (3\%) was less frequent than in infections at crisis. Neither cell nor nucleus showed hypertrophy.

TyPe LOcality: Achiote, Colon Province, Panama (09 $\left.12^{\prime} \mathrm{N}, 80^{\circ} 01^{\prime} \mathrm{W}\right)$.

TyPe SPECIEs: Anolis lionotus (Sauria: Iguanidae).

LOCATION OF TYPES: Disposition of type material for $P$. tropiduri tropiduri is unknown. Syntypes and parasyntypes of $P$. tropiduri panamense and $P$. tropiduri aquaticum are in the Telford collection. Parasyntypes have been deposited with Professor P.C.C. Garnham, Imperial College Field Station, Silwood Park, England ; Dr. R. Lainson, Instituto Evrandro Chagas, Belém, Brasil ; and Professor A.-G. Chabaud, Muséum National d'Histoire Naturelle, Paris.

COMPARISONS OF SUBSPECIES: In addition to differences of host and geographic range, $P$. tropiduri tropiduri is distinguished by having larger schizonts and gametocytes than do the other subspecies which are always prominently pigmented when parasitizing cells of the erythrocytic series. Its gametocytes tend to be more elongate in chronic than in active infections, in contrast to the other subspecies, while both schizonts and gametocytes cause hypertrophy of host cells and their nuclei during active infection. Schizonts and gametocytes of $P$. tropiduri panamense are intermediate in size between those of the other subspecies, and are seldom pigmented in active infections. Gametocytes tend to be more elongate in active than in chronic infections and cause hypertrophy of host cells and nuclei in active infection, but schizonts do not have this effect. Schizonts and gametocytes of $P$. tropiduri aquaticum are smallest of the subspecies and are always pigmented. Gametocytes tend to be more elongate in active than in chronic infections. Host cells may show hypertrophy when parasitized by schizonts and gametocytes, but their nuclei remain normal in size during active infection.

This taxonomic revision does not necessarily invalidate ecological observations on $P$. tropiduri presented elsewhere (Telford, 1977), inasmuch as 89 percent of the Panamanian infections studied came from three host species, A. biporcatus $(18 \%)$ and 
A. lionotus-poecilopus ( $71 \%$ ), but does possibly explain the bimodal peaks observed for newly acquired infections.

The Plasmodium species which parasitizes Anolis frenatus in central Panama was earlier identified as $P$. tropiduri (Telford, 1974, 1977). Study of additional material indicates that it is a distinct species allied to the $P$. minasense group which produces small schizonts and gametocytes, rather than being related to $P$. tropiduri. Those infections in A. frenatus reported as $P$. minasense (Telford, 1974, 1977) represent the crisis forms of the same species. With reference to the unusual tendency for all stages to lie at the periphery of the host cell, I designate the species :

\section{Plasmodium marginatum}

sp. nov.

Diagnosis: A saurian Plasmodium species with mature schizonts usually formed as flattened fans, and round to oval gametocytes which are smaller than uninfected erythrocyte nuclei. Schizonts produce 3-8 merozoites, with mean numbers of nuclei in individual infections less than seven. Immature asexual stages are highly amoeboid with prominent, often elongate cytoplasmic processes. All stages tend to lie along the host cell margin, and especially the asexual forms which assume elongated, flattened shapes.

Description: Trophozoites. Merozoites from newly ruptured schizonts were minute, $1 \mu \mathrm{m}^{2}$ to $1.5 \times 1 \mu \mathrm{m}$, usually showing cytoplasm but no pigment. With growth most became elongate and slender, $5 \times 1$ to $9 \times 1 \mu \mathrm{m}$, usually with one or both ends acuminate. Larger trophozoites showed light gold to dark pigment granules. Thicker trophozoites $5 \times 3-7 \times 2$ without indication of nuclear division perhaps were to become gametocytes. Schizonts. Binucleate schizonts were $4 \times 2-10 \times 2 \mu \mathrm{m}$ or 4-6 $\times 3 \mu \mathrm{m}$, with elongated shape associated with peripheral position. Large vacuoles were commonly seen, usually when an immature host cell was parasitized. Nuclei frequently lay widely separated within binucleate cells, but often were adjacent, in a line, when second division had occurred. The smallest tetranucleate immature schizont seen was $5 \times 3 \mu \mathrm{m}$. All asexual stages tended to be elongate and lie along the host cell margin, in single or multiple infections. Ends were often acuminate, extended into filiform cytoplasmic processes at either or both ends, although one end of the parasite was usually more blunt than the other. With maturity schizonts usually were formed as a fan $(72 \%)$, sometimes as rosettes $(12 \%)$, morula or in cruciform shape. Fans often were flattened in their peripheral position. The quantity of pigment remained modest though obvious. Mature schizonts were 3-6 $\times 2-4 \mu \mathrm{m}$, with average LW values in individual infections 13.0-15.1 $\mu \mathrm{m}^{2}$ (9-24). Nuclei were 3-8, with individual means 5.4-6.6. In an infection at crisis, schizonts were smaller, with LW 6-12 $\mu \mathrm{m}^{2}(\mathrm{x} 9.8 \pm .4$, $\mathrm{N}=25$ ), and 4-6 nuclei, $\mathrm{x} 4.1 \pm .2$. All seen were pigmented. Gametocytes. The smallest forms clearly gametocytes were rounded, $4 \times 4 \mu \mathrm{m}$, with differential staining 
by sex not yet evident in those reaching $6 \times 3 \mu \mathrm{m}$. Pigment was clumped in a yellow mass, usually in one focus. Mature gametocytes were $5-9 \times 4-7 \mu \mathrm{m}$, with mean LW values 26.7-35.8 $\mu \mathrm{m}^{2}$ (20-54). Most were round (84\%) in active infections to oval $(74 \%)$ in acute phase, with elongate forms rare $(4 \%)$, and $\mathrm{L} / \mathrm{W}$ ratios averaging $1.19-1.47(1.0-2.0)$, respectively. Their size relative to host cell nucleus averaged $0.66-$ $0.82(0.4-1.2)$. All seen were pigmented with small dark granules scattered in the cytoplasm.

EFFECTS UPON HOST CELLS : Slightly more schizonts occupied polar (36\%) or lateropolar positions than were lateral $(28 \%)$, and they commonly distorted host cells $(23 \%)$ or their nuclei $(15 \%)$, and displaced the latter $(19 \%)$. They were usually on the periphery of the cell $(81 \%)$. Gametocytes occupied polar $(53 \%)$ or lateropolar positions, but were commonly lateral to host cell nucleus as well (19\%). Fewer were more clearly on the cell margin $(32 \%)$ than were schizonts. Host cells were often distorted $(56 \%)$, nuclei less commonly $(24 \%)$, but the latter were sometimes displaced $(42 \%)$. Both schizonts and gametocytes caused significant host cell hypertrophy but nucleus size was not affected. In the crisis stage both cell and its nucleus showed hypertrophy when parasitized by schizonts.

EXOERYTHROCYTIC STAGES: No exoraerythrocytic stages known to belong to this species were seen.

TyPe HOST: Anolis frenatus (Sauria: Iguanidae).

TYPe LOCALITY: Frijoles River, $5 \mathrm{~km} \mathrm{~N}$ of Gamboa, Canal Zone, Panama $\left(9^{\circ} 10^{\prime}\right.$ N, $79^{\circ} 49^{\prime}$ W).

Geographical RANGe: Known only from central Panama.

LOCATION OF TYPES : Syntype and parasyntype slides are in the Telford collection. Other paratypes are deposited with Professor G.H. Ball, Department of Biology, University of California, Los Angeles; with Professor P.C.C. Garnham, and with Professor A.-G. Chabaud, at institutions listed above.

The malaria parasite found in Anolis limifrons in Panama is an undescribed species, as suggested by Guerrero et al. $(1977 a)$. It was considered to be $P$. tropiduri earlier (Telford, 1974) on the basis of schizonts, as I had no infections showing its characteristically elongate mature gametocytes which easily distinguish it from that species. I have examined new material recently and provide below a synopsis of this species which I will not formally describe inasmuch as Dr. Ayala is studying it.

\section{Plasmodium sp. from Anolis limifrons}

SyNOPSIS : A saurian Plasmodium with schizonts and gametocytes which approximate the host cell nucleus in active infections. Schizonts are 4-10 $\times 4-7 \mu \mathrm{m}(\overline{\mathrm{x}} 5.8$ $7.6 \times 4.5-5.8$ ), with LW averaging 26.0-44.1 $\mu \mathrm{m}^{2}$ (16-70), and contain 6-12 nuclei, with means of individual infections 7.7-9.4. Nuclei are usually arranged as a rosette 
$(58 \%)$ or as a fan $(33 \%)$, less commonly otherwise. Their position within cells is usually polar $(80 \%)$ or lateropolar to the nucleus, and they cause very little distortion of host cell and nucleus $(2 \%)$ but often displace it $(51 \%)$. Immature asexual stages are amoeboid, often showing short cytoplasmic processes, and may occupy any position within the cell. Gametocytes are 6-16 $\times 4-7 \mu \mathrm{m}(\overline{\mathrm{x}} 10.4 \pm .3 \times 4.8 \pm .1, \mathrm{~N}=$ 50 ), with LW values averaging $49.7 \pm 1.3 \mu \mathrm{m}^{2}$ (30-75). Most are elongate $(80 \%)$, with $\mathrm{L} / \mathrm{W}$ ratios averaging $2.20 \pm 0.8(1.1-4.0)$. They average larger than the host cell nucleus, $1.37 \pm .07(0.7-2.7)$, and are usually lateropolar (48\%), curving somewhat around the host cell nucleus, commonly adopting a polar position $(40 \%)$, or lying lateral to the nucleus. A vacuole was visible in many gametocytes (58\%). Possibly because of the tendency to curve arond host cell nuclei, few host cells show distortion $(8 \%)$, and nuclei are rarely distorted $(4 \%)$ or displaced $(2 \%)$. Immature gametocytes are usually elongate with pigment clumped together in a single locus. Neither schizonts nor gametocytes produce significant hypertrophy of host cells or nuclei.

\section{The Malarial Parasites of Plica plica}

Elsewhere (Telford, 1973) I have reported the presence of two Plasmodium species in the lizard Plica plica in Guyana, designating a medium-size parasite as P. uncinatum and identifying a species which produces large schizonts as $P$. cnemidophori. Study of many infections of $P$. cnemidophori from Venezuela Ameiva ameiva indicates that the population parasitizing $P$. plica is readily distinguished by its immature stages and gametocytes, being similar to $P$. cnemidophori only in appearance of the mature schizonts. It is necessary, therefore, to provide a description of this species. I designate it :

\section{Plasmodium guyannense}

sp. nov.

Diagnosis : A Plasmodium parasite of iguanid lizards characterized by schizonts and gametocytes 2-5 times as large as nuclei of uninfected erythrocytes. Schizonts produce 40-74 merozoites in round or oval segmenters which nearly fill host cells, laterally displacing nuclei, with a large, irregular mass of dark pigment usually centrally located in the parasite. Gametocytes are round to elongate and bulky, with both size and shape differing by sex. Macrogametocytes, usually elongate, average one-fourth larger than the round or oval microgametocytes.

Description: Trophozoites. The smallest parasites seen were $1.5 \times 1 \mu \mathrm{m}$, with no cytoplasm visible but with a narrow margin on one side which probably represented the developing vacuole. At $2 \times 1.5 \mu \mathrm{m}$, the cytoplasm formed a triangular to oval outline, usually surrounding a prominent vacuole, but lacked pigment which did not appear until trophozoites were $4 \times 3 \mu \mathrm{m}$. The largest trophozoites seen were 
$6 \times 3 \mu \mathrm{m}$ with large, pale yellow pigment masses which usually lay within the vacuole. Vacuoles began to disappear after parasites reached $5 \times 2 \mu \mathrm{m}$ in size. Schizonts. The smallest binucleate schizonts were $7 \times 4 \mu \mathrm{m}$, with pigment mass prominent but no vacuole present. Tetranucleate schizonts were 5-10 $\times 5 \mu \mathrm{m}$, and nuclear division proceeded slowly from this point, with nuclei well dispersed in the cytoplasm until after the fifth division when they began to fill the schizont. Mature schizonts were round or oval, with very small nuclei and a large, dark pigment mass often centrally located. Their dimensions were 10-15 × 6-12 $\mu \mathrm{m}(\mathrm{x} 12.3 \pm .2 \times 10.2 \pm .3, \mathrm{~N}=30)$, with LW values averaging $126.2 \pm 4.3 \mu \mathrm{m}^{2}$ (72-180), and they contained 40-74 nuclei ( $\overline{\mathrm{x}} 56.4 \pm 1.7$ ). Gametocytes. The smallest parasites clearly identifiable as gametocytes were $6 \times 4 \mu \mathrm{m}$, with large pigment mass but with vacuole presence variable. In gametocytes as small as $7 \times 7 \mu \mathrm{m}$, differential staining by sex was evident. Pigment remained clumped in a single locus in parasites as large as $10 \times 6-14 \times 4 \mu \mathrm{m}$, after which it dispersed as small dark granules throughout the cytoplasm. Mature gametócytes were $8-17 \times 5-10 \mu \mathrm{m}(\overline{\mathrm{x}} 12.2 \pm .3 \times 7.1 \pm .2, \mathrm{~N}=60)$, with $\mathrm{LW}$ averaging $86.7 \pm 2.8(54-144)$, and $\mathrm{L} / \mathrm{W}$ ratio $1.77 \pm .06(1.0-3.0)$. Their size relative to host cell nucleus averaged $1.91 \pm .07(0.9-3.2)$. Inasmuch as macrogametocytes averaged $13.5 \pm .3 \mu \mathrm{m}$ in length in contrast to $10.4 \pm .3 \mu \mathrm{m}$ for microgametocytes, there were significant differences by sex in both $\mathrm{LW}$ and $\mathrm{L} / \mathrm{W}$ values. Macrogametocytes were $60-144 \mu \mathrm{m}^{2}(\overline{\mathrm{x}} 94.1 \pm 3.5, \mathrm{~N}=35)$ with $\mathrm{L} / \mathrm{W} 1.2-3.0(\overline{\mathrm{x}} 2.01 \pm .08)$ in comparison to microgametocytes which had LW $54-134 \mu \mathrm{m}^{2}(\overline{\mathrm{x}} 76.3 \pm 3.8, \mathrm{~N}=25)$ and $\mathrm{L} / \mathrm{W}$ $1.0-2.2(\mathrm{x} 1.43 \pm .05)$. Mature gametocytes rarely showed vacuoles $(3 \%)$.

EXOERYTHROCYTIC STAGES: No exoerythrocytic stages were seen on impression smears from liver, lungs, spleen and bone marrow.

EFFECTS UPON HOST CELLS: Trophozoites parasitized proerythrocytes more commonly than erythrocytes but these were usually polychromatophilic rather than basophilic in staining reaction. Schizonts were usually in erythrocytes as were mature gametocytes, although young gametocytes were seen more commonly in proerythrocytes. Schizonts occupied lateral positions in host cells and this always produced hypertrophy and distortion of the host cell as well as nuclear displacement. Nuclei usually were distorted $(93 \%)$ but did not show hypertrophy. Gametocytes were usually lateral $(81 \%)$ or lateropolar, rarely polar $(2 \%)$. Host cells were distorted always and their nuclei usually displaced (93\%) and commonly distorted $(28 \%)$. Both host cell and nucleus showed hypertrophy.

TYPE HOST: Plica plica (Sauria: Iguanidae).

GEOGRAPHIC RANGE : Known only from the type locality, vicinity of Georgetown, Guyana.

DisPosition OF TYPES : Syntype and parasyntype slides awaiting deposition with Telford collection. Parasyntype slides deposited with Professor P.C.C. Garnham, with Professor A.-G. Chabaud, and with Dr. R. Lainson, at their respective institutions listed above. 
COMPARISONS WITH OTHER SPECIES: Plasmodium guyannense is superficially similar to $P$. cnemidophori and $P$. achiotense but is readily distinguished from the other large New World saurian malaria, $P$. balli, by the absence of pigment in the latter species. Schizonts of $P$. cnemidophori (Venezuelan strains) are larger, 130$266 \mu \mathrm{m}^{2}$, and contain more nuclei, 67-127, with the average number exceeding the maximum seen in P. guyannense. Schizonts from Guyanan P. cnemidophori available for comparison were more similar, 104-156 $\mu \mathrm{m}^{2}$, with 58-87 nuclei. Characteristics of younger asexual stages readily distinguish them: trophozoites of $P$. cnemidophorl lack prominent vacuoles, while pigment is never obvious as a large mass in the smaller asexual and sexual stages. These show a clear tendency for younger proerythrocytes, while developing schizonts of comparable size to those of $P$. guyannense contain more nuclei, suggesting a faster rate of division. Immature gametocytes of $P$. cnemidophori are always elongate, not round or oval, while the «banana-shape » of newly mature gametocytes is rarely seen in the iguanid parasite. Gametocytes are similar but sexual differences in size and shape are less great in P. cnemidophori. These almost always show a single vacuole, which is rarely seen in $P$. guyannense. Schizonts of $P$. achiotense contain fewer nuclei (36-56) which are larger in size and form somewhat larger schizonts (LW 100-221 $\mu \mathrm{m}^{2}$ ). Gametocytes of $P$. achiotense average larger in LW $\left(105 \mu \mathrm{m}^{2}\right)$ and do not show sexual differences in size or shape, being round or oval rather than elongate.

\section{The identity of malarial parasites from Plica umbra of Guyana.}

In my study of malarial parasites from Guyana lizards (Telford, 1973), I reported infections from Plica umbra as erythrocytic and thrombocytic stages of Plasmodium tropiduri, influenced by Scorza's (1972) demonstration of a thrombocytic cycle of schizogony and gametogony for this species in Venezuelan Tropidurus hispidus. Although disturbed by the relatively large amount of pigment in the erythrocytic forms, I did not want to provide yet another species description on the basis of my limited material. Lainson et al. (1974), with much more material available, described the erythrocytic parasite as Plasmodium vacuolatum. This appears to me to be a valid species, and the Guyana parasites are clearly the same. These workers have designated the thrombocytic parasite of $P$. umbra as Fallisia simplex of the Garniidae. I have been reluctant to accept Fallisia as a genus primarily because of Scorza's work on P. tropiduri (1972) and my own study of $P$. azurophilum (Telford, 1975) in the Greater Antilles, suspecting that the thrombocytic/leucocytic cycles could be a defense by the parasite against host immunological attack. This cannot be tested without vector transmission or evidence of specific identity from biochemical studies. My recent discovery of Fallisia in southeast Asian lizards leads me to support Fallisia as a plasmodiid genus, without acceptance of the Garniidae. Accordingly, it is clear that the thrombocytic parasites I reported in Plica umbra should be identified as Fallisia simplex.

The taxonomic arrangement of the iguanid malarias related to Plasmodium tropiduri presented above will be modified certainly, once more basic, non-morphological 
data become available. It is not very important whether the three $P$. tropiduri populations identified here are considered to be subspecies or distinct species, as long as the concept of an evolutionary line diverging in separate host species and thereby expanding its geographical/ecological range is recognized. A classification of malarial parasites based upon morphology, presence or absence of pigment and type of host cell parasitized will remain inadequate and controversial unless supported by evidence from studies of sporogonic pattern, primary exoerythrocytic schizogony, biochemical and immunological relationships.

It is hoped that study of the complex ecological relationships of saurian malarias and their hosts in the Neotropics can proceed with less interest in proving my earlier identifications to be wrong (Telford, 1973, 1974, 1977). Neither the Plasmodium found in Anolis limifrons in Panama (and possibly A. fuscoauratus of Peru, vide Guerrero et Ayala, 1977), nor P. marginatum described above is conspecific with $P$. tropiduri as I have defined it here. Preoccupation with obviously inadequate classifications based upon morphology alone should not detract from the real necessity to obtain more basic data by those with such opportunities available.

\section{Bibliography}

Ayala S.C. (1977): Plasmodia of Reptiles, p. 267-309, in: Parasitic Protozoa. Vol. III. Gregarines, Haemogregarines, Coccidia, Plasmodia and Haemoproteids. J.P. Kreier, Ed. Academic Press, édit., New York.

Ayala S.C., Spain J.L. (1976) : A population of Plasmodium colombiense sp. n. in the iguanid lizard, Anolis auratus. J. Parasitol., 62, 177-189.

Garnham P.C.C. (1966): Malaria Parasites and Other Haemosporidia. Blackwell Sci. Publ., Oxford, $1118 \mathrm{p}$.

Guerrero S., Ayala S.C. (1977) : Hemoparasitos de algunos reptiles y anfibios de la selva Amazonica del Peru. Rev. Inst. Med. Trop. S. Paulo, 19, 283-288.

Guerrero S., Rodriguez C., Ayala S.C. (1977): Prevalencia de hemoparasitos en lagartijas de la Isla Barro Colorado, Panama. Biotropica, 9, 118-123.

Lainson R., Shaw J.J., Landau I. (1975): Some blood parasites of the Brazilian lizards Plica umbra and Uranoscodon superciliosa (Iguanidae). Parasitol., 70, 119-141.

Scorza J.V. (1971): Asexual and sexual stages of a malaria parasite in the thrombocytes of Tropidurus torquatus (Iguanidae) infected with Plasmodium tropiduri. J. Protozool., 18, 403-410.

Telford S.R., Jr. (1973): Saurian malarial parasites from Guyana: their effect upon the validity of the family Garniidae and the genus Garnia, with descriptions of two new species. Int. J. Parasitol., 3, 829-842.

Telford S.R., Jr. (1974): The malarial parasites of Anolis species (Sauria, Iguanidae) in Panama. Int. J. Parasitol., 4, 91-102.

Telford S.R., Jr. (1975): Saurian malaria in the Caribbean: Plasmodium azurophilum sp. nov., a malarial parasite with schizogony and gametogony in both red and white blood cells. Int. J. Parasitol., 5, 383-394.

Telford S.R., Jr. (1977): The distribution, incidence and general ecology of saurian malaria in Middle America. Int. J. Parasitol., 7, 299-314. 